\title{
ЭКОЛОГИЯ
}

И ПРИРОДОПОЛЬЗОВАНИЕ

DOI: https://doi.org/10.15688/nsr.jvolsu.2019.1.5

UDC $630 * 181.28$

LBC 26.8

\section{FOREST-GROWING CONDITIONS AND STATE OF PINE AND BIRCH SPECIES IN THE NORTHERN PART OF THE SUBURBAN ZONE OF VOLGOGRAD ${ }^{1}$}

\author{
Olga Yu. Kosheleva \\ Federal Scientific Centre of Agroecology, Complex Melioration and Protective Afforestation \\ of the Russian Academy of Sciences, Volgograd, Russian Federation \\ Alexander V. Koshelev \\ Federal Scientific Centre of Agroecology, Complex Melioration and Protective Afforestation \\ of the Russian Academy of Sciences, Volgograd, Russian Federation \\ Stanislav S. Shinkarenko \\ Federal Scientific Centre of Agroecology, Complex Melioration and Protective Afforestation \\ of the Russian Academy of Sciences, Volgograd State University, Volgograd, Russian Federation
}

\begin{abstract}
The article presents the results of the assessment of forest conditions and the state of forest cultures of Scots pine and Silver birch in the suburban area of Volgograd. The relevance of the study is due to the need to select productive and resistant to dry conditions mixing schemes of tree species for the organization of forest-park areas in suburban areas of large cities. Studies were conducted on the example of a key area of 0,7 hectares in the northern part of the city. Soil forest availability was determined by the granulometric composition, organic matter content and ㄱ groundwater level. Soil sections of light chestnut soils are described, the characteristics of the main physicochemical $\hat{j}$ indicators of soils are given. A profile of groundwater occurrence has been compiled and its relationship with the relief $\dot{y}$ of the site is shown. The condition of forest cultures was assessed by bonitet, stock and vital status of the stand. High vitality indicators of pine and birch testify to the optimal conditions for the growth of forest crops under dry pinery. The conducted research allowed recommending, during the silvicultural works in the north of the suburban zone of Volgograd, the cool way of mixing pine with birch to create highly productive and sustainable protective forest stands. level, stand viability.

УДК $630 * 181.28$

ББК 26.8
\end{abstract}

\section{ЛЕСОРАСТИТЕЛЬНЫЕ УСЛОВИЯ И СОСТОЯНИЕ СОСНОВО-БЕРЕЗОВЫХ НАСАЖДЕНИЙ В СЕВЕРНОЙ ЧАСТИ ПРИГОРОДНОЙ ЗОНЫ ВОЛГОГРАДА ${ }^{1}$}

\section{Ольга Юрьевна Кошелева}

Федеральный научный центр агроэкологии, комплексных мелиораций и защитного лесоразведения Российской академии наук, г. Волгоград, Российская Федерация 


\section{Александр Валентинович Кошелев}

Федеральный научный центр агроэкологии, комплексных мелиораций и защитного лесоразведения Российской академии наук, г. Волгоград, Российская Федерация

\section{Станислав Сергеевич Шинкаренко}

Федеральный научный центр агроэкологии, комплексных мелиораций и защитного лесоразведения Российской академии наук;

Волгоградский государственный университет, г. Волгоград, Российская Федерация

Аннотация. В статье представлены результаты оценки лесорастительных условий и состояния лесных культур сосны обыкновенной и березы повислой в пригородной зоне Волгограда. Актуальность исследования обусловлена необходимостью отбора продуктивных и устойчивых к засушливым условиям схем смешения древесных пород для целей организации лесопарковых территорий в пригородных зонах крупных городов. Исследования проводились на примере участка площадью 0,7 га в северной части города. Лесопригодность почв определялась по гранулометрическому составу, содержанию органического вещества и уровню залегания грунтовых вод. Описаны почвенные разрезы светло-каштановых почв, дана характеристика основных физико-химических показателей почв. Составлен профиль залегания грунтовых вод и показана его связь с рельефом участка. Состояние лесных культур оценивалось по бонитету, запасу и жизненному состоянию древостоя. Высокие показатели жизнеспособности сосны и березы свидетельствуют об оптимальных условиях произрастания лесных культур в условиях сухого бора. Проведенные исследования позволили рекомендовать при проведении лесокультурных работ на севере пригородной зоны Волгограда кулисный способ смешения сосны с березой для создания высокопродуктивных и устойчивых защитных лесных насаждений.

Ключевые слова: Волгоград, пригородная зона, зеленый пояс, сосна обыкновенная, береза повислая, светло-каштановые почвы, уровень грунтовых вод, жизнеспособность древостоя.

Введение. Лесопарковые защитные пояса - важное звено в градостроительной концепции развития любого крупного города, и Волгоград не является исключением. В развитых странах различные озелененные территории - поля, сады, луга, лесные массивы - обеспечивают улучшение городской среды и выполняют важную архитектурнохудожественную задачу, органически связывая городской и пригородный ландшафты [16; 17 ; 19-21].

В Волгограде работы по созданию защитного зеленого пояса по западным границам города начались в 1930-х гг. и были продолжены в послевоенное время. С помощью древесно-кустарниковой растительности закреплялись пески, овраги и балки. На песках высаживалась сосна обыкновенная, на лучших почвенных разностях - береза повислая, дуб черешчатый, каштан конский, катальпа, скумпия, по солонцам - тамарикс и лох. Одновременно создавались плодово-ягодные сады и виноградники [4]. В последнее время зеленый пояс Волгограда находится под угрозой исчезновения: лесные культуры достигли своего предельного возраста, повреждены болезнями и вредителями, ежегодно горят и вы- рубаются под жилищно-коммунальное строительство. Лесокультурные работы на территории городских лесничеств проводятся в масштабах, недостаточных для своевременного обновления лесопокрытой площади. В этих условиях актуально проведение исследований в сохранившихся насаждениях зеленого пояса с целью выявления высокодекоративных, продуктивных и устойчивых в условиях засушливого климата древостоев и схем смешения, перспективных для внедрения при реконструкции старых и организации новых лесопарков в пригородной зоне Волгограда. Одним из таких типов насаждений в северной части пригородного защитного пояса Волгограда может выступать кулисное смешение сосны обыкновенной и березы повислой. В целом такое сочетание лесных культур имеет широкое распространение в естественных и искусственных насаждениях лесостепной и степной зон $[11 ; 15 ; 18]$. Так, В.К. Поповым [10] были установлены закономерности повышения устойчивости сосны в сосново-березовых культурах к неблагоприятным факторам внешней среды. Между тем, есть и противоположное мнение о неблагоприятном воздействии биологически активных 
соединений березы на сосну [11]. Эти две породы объединяет малотребовательность к внешней среде и широкая экологическая пластичность, то есть способность произрастать в самых разнообразных условиях, что и обусловливает их высокую лесохозяйственную значимость. Однако, в целом, по мере продвижения на юг и ухудшения лесорастительных условий, рост березы в высоту значительно снижается, а продолжительность жизни резко падает. Так, в районе Камышина на темнокаштановых почвах продолжительность жизни березы в лесных полосах не превышает 3040 лет, в отличие от 40-60 лет в лесостепи и черноземной степи [5].

Таким образом, цель настоящей работы - изучить современное состояние сосново-березовых насаждений в пригородной зоне Волгограда в зависимости от уровня залегания грунтовых вод и почвенных условий, определяющих водообеспеченность древостоя.

Объект и методы исследований. Ключевой участок расположен на территории Тракторозаводского района г. Волгограда, в пос. Латошинка (рис. 1). Центр участка имеет координаты $48^{\circ} 51^{\prime}$ 41" с.ш. и 44 39' 13" в.д. На данной территории произрастает небольшой массив (около 0,7 га) лесных культур со- сны обыкновенной (Pinus silvestris L.) и березы повислой (Betula pendula Roth).

B геоморфологическом отношении участок расположен на восточном склоне Приволжской возвышенности Восточно-Европейской равнины, севернее Волжской ГЭС, в 250 м от Волгоградского водохранилища и в 800 м на северо-восток от Латошинского песчаного карьера. Рельеф участка относительно ровный, характеризуется отметками $50,5-$ 55,9 м, с уклоном поверхности в сторону водохранилища.

Климат территории характеризуется резкой континентальностью с холодной малоснежной зимой и сухим жарким летом. Годовое количество осадков составляет в среднем 420 440 мм [1].

В геологическом отношении территория представлена современными делювиальными отложениями (песок и суглинок), подстилаемыми песчано-алевритовой породой мечеткинской свиты палеогеновой системы. Современные делювиальные отложения представлены песком светло-серым, мелким с прослоями песка пылеватого и средней крупности, глинистым, с линзами супеси. Суглинок серовато-коричневый, текучепластичный, легкий, опесчаненный, залегает в виде прослоя в пес-

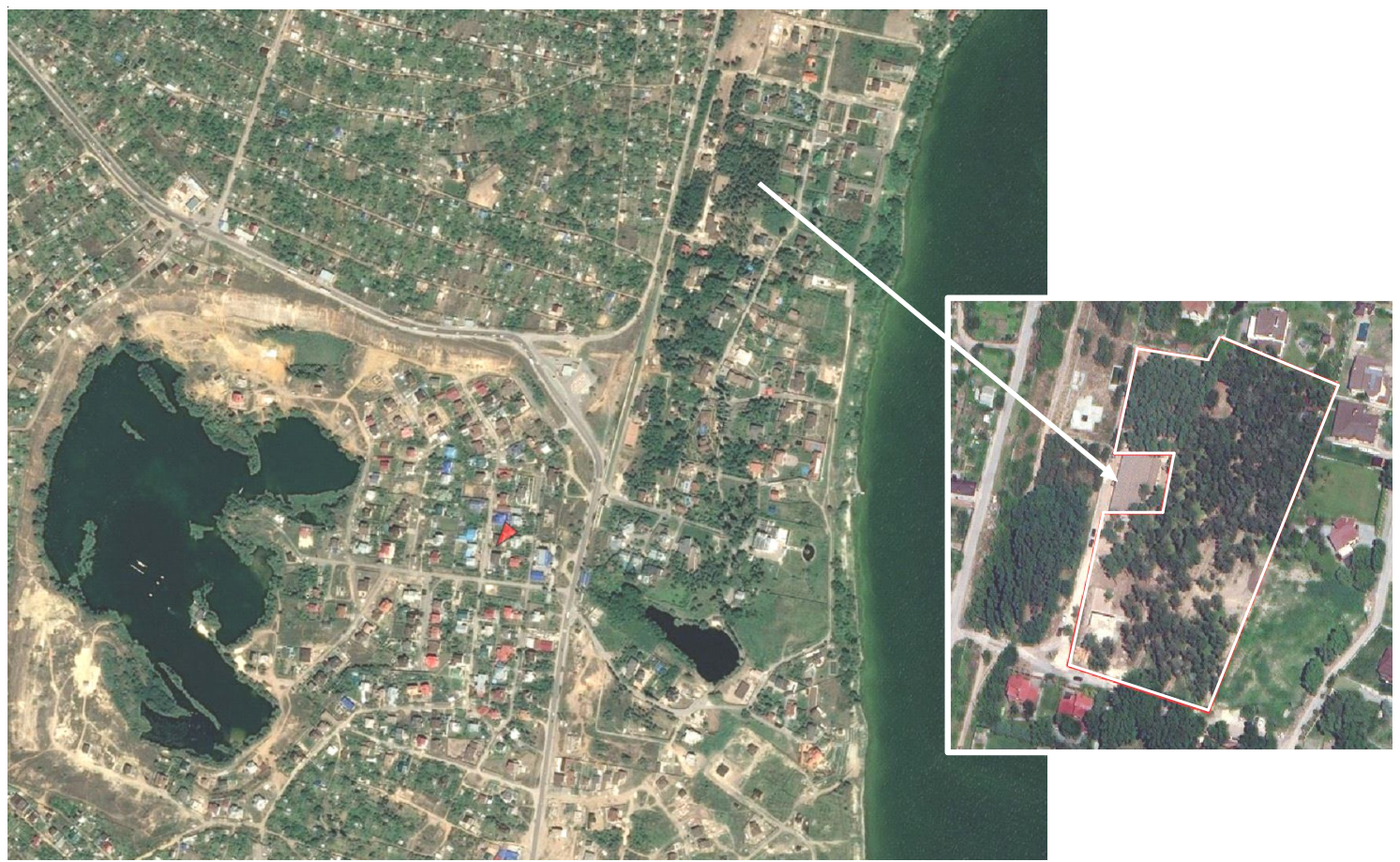

Рис. 1. Объект исследования - сосново-березовый массив в пос. Латошинка 


\section{ЭКОЛОГИЯ И ПРИРОДОПОЛЬЗОВАНИЕ}

ке. Мечеткинская свита палеогеновой системы представлена песчано-алевритовой породой на глинистом цементе, темно-серой с зеленоватым оттенком [1; 13].

Гидрогеологические условия ключевого участка характеризуются наличием подземных вод в современных делювиальных песках и суглинках на глубине 2,9-3,8 м. Уровень подземных вод подвержен сезонным колебаниям с амплитудой до 1,5 м в зависимости от атмосферных осадков.

В качестве исходной информации для составления дендроплана участка использовался космический снимок WorldView-3 [22]. Натурные обследования лесных насаждений на участке с закладкой шурфов и почвенного разреза проводились в августе 2018 года. Таксация древостоя на участке проводилась сплошным перечетом деревьев с определением основных лесоводственных характеристик: высоты, диаметра, возраста, состояния, запаса и бонитета насаждений [2]. Категория состояния деревьев определялась по 6-балльной шкале Е.Г. Мозолевской [8].

Уровень грунтовых вод (УГВ) определялся методом бурения с помощью ручного почвенного бура. Отдельно в сосновом и березовом насаждениях были заложены 2 почвенных профиля глубиной $1,7-1,8$ м, описание которых и определение основных физикохимические показателей (гранулометрический состав, содержание органического вещества, карбонатность и т. д.) проводились по общепринятым методикам [14]. Для определения УГВ было заложено 3 шурфа глубиной 2,03,0 м по трансекте: точка А - в сосновом насаждении, точка Б - на границе соснового и березового древостоев, точка В - в березовом насаждении.

Результаты исследования. По результатам полевого дешифрирования космического снимка был составлен дендроплан ключевого участка сосново-березовых насаждений - чертеж, на который наносятся контуры всех зеленых насаждений, расположенных на участке в момент обследования (см. рис. 2). Кроме того, при необходимости, на нем изображаются дополнительные элементы участка (границы, постройки, дороги и т. д.). В данном случае на дендроплане были зафиксированы точки почвенного бурения для опреде- ления УГВ и места закладки почвенных разрезов, а также показан ареал низового пожара. Дендроплан необходим для визуального представления пространственной организации лесопокрытого участка и планирования работ по озеленению.

Насаждения на обследуемом участке создавались искусственным путем кулисами, рядовым способом. Всего насчитывается 9 рядов сосны обыкновенной с расстоянием междурядий от 3,8 до 4,8 м, и 4 ряда березы повислой с расстоянием междурядий от 4 до 5 м (см. рис. 3). Напочвенный покров представлен разреженными разнотравно-полынными и разнотравно-злаковыми сообществами, в сосновом насаждении - подстилкой из сухой хвои. Встречается единичный подрост из клена ясенелистного и ясеня зеленого высотой 0,3-1,0 м.

Лесопригодность почв на ключевом участке определяется, в первую очередь, особенностями водного потенциала почвогрунтов [6]. На почвах легкого гранулометрического состава насаждения сосны незначительно реагируют на изменение атмосферных осадков и менее подвержены стрессовым ситуациям во время засух, в отличие от деревьев на более тяжелых по гранулометрическому составу и богатых по минеральному питанию почв. Объясняется это тем, что из-за малой влагоемкости легкие почвы не накапливают большого количества продуктивной влаги и запас ее стабилен по сезонам года. Несмотря на то, что на тяжелых почвах насаждения в первые годы растут быстрее и накапливают значительную ассимиляционную массу, в дальнейшем они оказываются более чувствительными к недостатку выпадающих осадков из-за своей высокой потребности во влаге. Поэтому, как отмечает большинство исследователей, по мере увеличения сухости климата лесопригодность смещается в сторону менее влагоемких бедных почвогрунтов легкого гранулометрического состава $[3 ; 6 ; 7 ; 12]$.

Светло-каштановые почвы на ключевом участке характеризуются следующими морфологическими признаками.

Разрез № 1. Ровный участок под березовым насаждением.

A 0 0-10 см - ржаво-коричневый, супесчаный, сухой, рыхлый, мелкокомковатый, мно- 
го корней травянистой и древесной растительности. Переход резкий.

А 2 10-20 см - желто-коричневый, песчаный, сухой, рыхлый, мелкокомковатый; пронизан корнями древесной растительности. Переход резкий.

В 1 20-80 см - бурый, супесчаный, свежий, плотноватый, комковатый, встречаются единичные корни деревьев. Переход постепенный.
В 20-100 см - светло-бурый, супесчаный, влажный, плотноватый, комковатый, корней нет. Переход резкий.

С 100-180 см - темно-бурый, супесчаный, сырой, на глубине 180 см вскрывается водоносный горизонт.

Разрез № 2. Ровный участок под сосновым насаждением.

А 0-5 см - лесная подстилка, цвет темный.

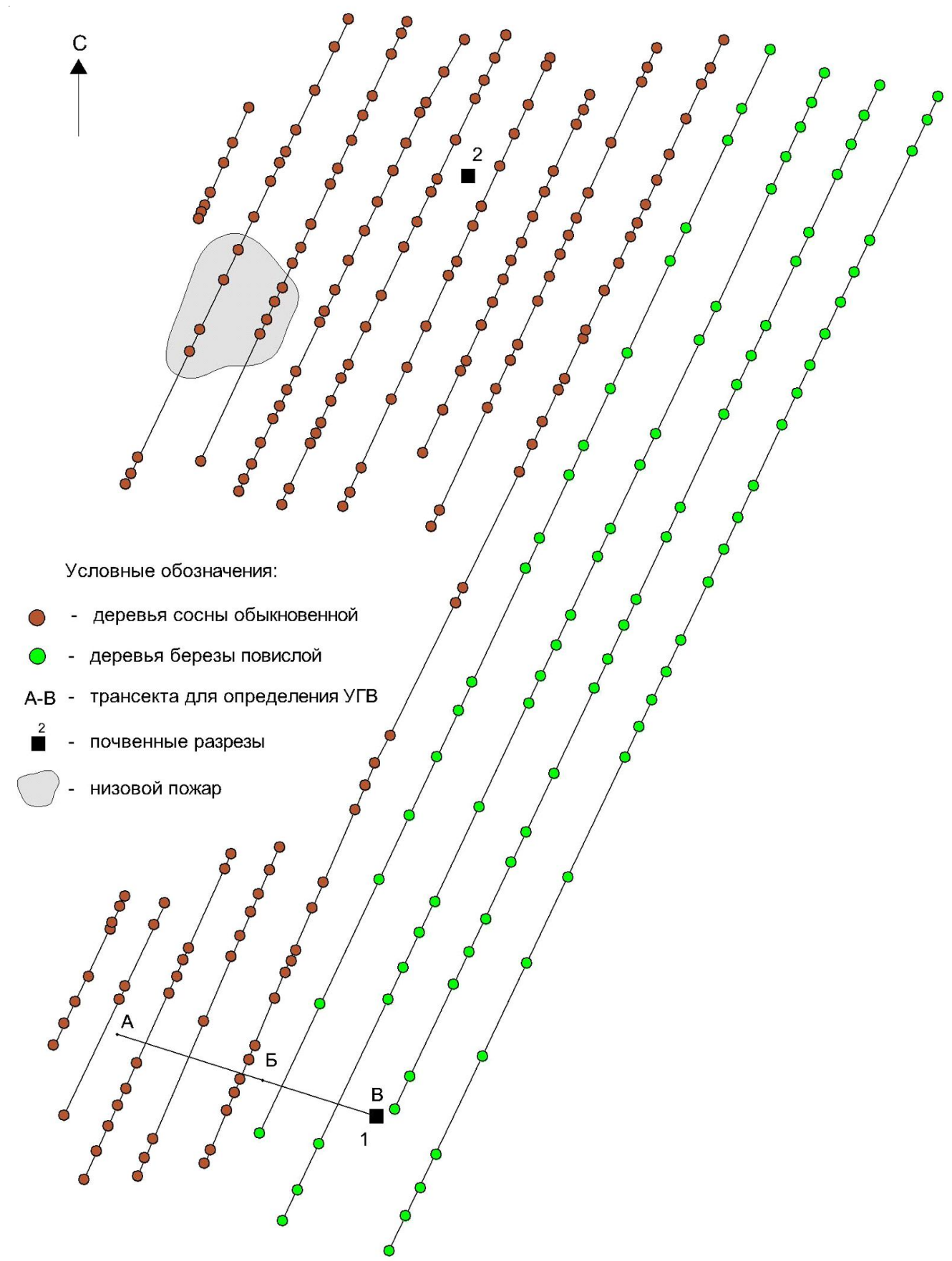

Рис. 2. Дендроплан ключевого участка 


\section{ЭКОЛОГИЯ И ПРИРОДОПОЛЬЗОВАНИЕ}

А 5-17 см - светло-коричневый с охристым оттенком, легкий суглинок, сухой, рыхлый, крупнокомковатый, пронизан корнями деревьев. Переход ясный.

В 17-30 см - серо-коричневый, песчаный, сухой, рыхлый, пылеватый, корней нет. Переход резкий.

В $\mathbf{2 0}$ 3080 см - коричневый, супесчаный, сухой, плотный, мелкокомковатый. Переход ясный.

C - 80-150 см - темно-коричневый, супесчаный, свежий, плотный.

Из морфологического и физико-химического анализа почвенных разрезов видно, что на обследуемом участке почвы светло-каштановые, преимущественно, легкого гранулометрического состава - супесчаного и легкосуглинистого. Горизонты меняют окраску по степени насыщения их влагой. Почва маломощная, укороченного профиля, незасоленная, слабогумусированая (содержание гумуса в горизонте А+B не превышает 1,03-1,08 \%). Наличие карбонатов $\left(\mathrm{CaCO}_{3}\right)$ выявлено в обоих разрезах до глубины $20 \mathrm{~cm}$, их содержание колеблется от 1,2 до $1,7 \%$.
В связи с повышенной динамичностью атмосферного увлажнения, одним из условий выращивания сосново-березовых культур в засушливой степи является оптимальная глубина залегания грунтовых вод, которая в разных природных зонах и для разных древесных пород имеет свои верхние и нижние пределы и которая определяет ее доступность в критические периоды жизни насаждений. Так для сосны на кварцевых песках, критической считается залегание верховодки глубже 3 м, на полиминеральных песках - 6-7 м и более [6]. При этом высокий подъем ГВ также отрицательно влияет на лесопригодность почв: ухудшается аэрация почвенной толщи, что приводит к азотно-зольному голоданию деревьев и их гибели [9].

На ключевом участке глубина залегания грунтовых вод колеблется от 1,4 до 1,8 м. Уровень ГВ коррелирует с рельефом и закономерно поднимается к дневной поверхности по мере продвижения к Волгоградскому водохранилищу (см. рис. 4). Таким образом, насаждения, расположенные ниже по склону имеют в своем распоряжении более доступную верховодку. Таким образом, условия про-

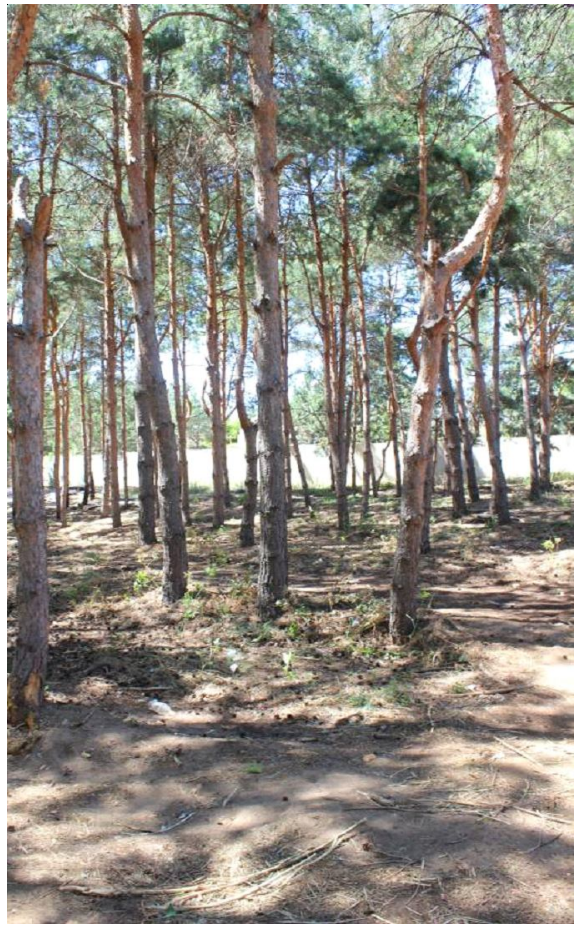

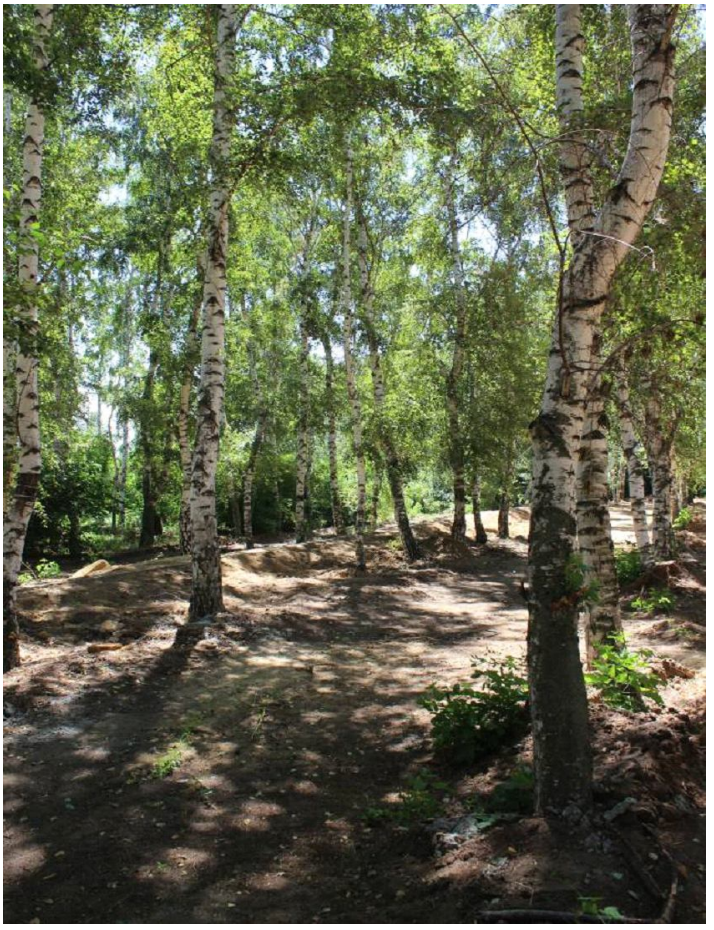

6

Рис. 3. Насаждения сосны обыкновенной (a) и березы повислой (б) в пос. Латошинка 
израстания древесных насаждений на данном участке соответствуют сухому бору (A1).

В результате проведенной таксации лесных культур был осуществлен сплошной пересчет всех деревьев в границах обследуемого участка с определением основных ростовых характеристик древостоя (высота и диаметр дерева, возраст и визуальная оценка жизнеспособности деревьев).

Лесные культуры были заложены в 1986 г. За это время сосна достигла средней высоты 13,9 м, береза - 19,2 м, что соответствую I классу бонитета. Общий запас древесины на участке составляет 69,2 м³, из которых 63,6 \% приходится на сосновый древостой. При этом данные таблицы 1 показывают, что береза по средним ростовым показателям обогнала сосну. Это может быть обус- ловлено улучшением морфологических, физико-химических и гидрогеологических условий вниз по склону, обусловливающих рост и развитие культур березы, в частности, более близкое залегание грунтовых вод.

Обследование 2018 г. показало, что к настоящему времени сохранность и сосны и березы на данном участке достаточно высокая (табл. 2).

Ослабленные деревья сосны зафиксированы в ареале низового пожара, который привел к обгоранию и механическим повреждениям нижней части стволов. Береза более разрежена в рядах, в пологе имеются крупные прогалы. Среди деревьев березы есть сухостой прошлых лет. Их усыхание может быть вызвано погодными условиями, например, крайне сухое и жаркое лето 2010 г., или

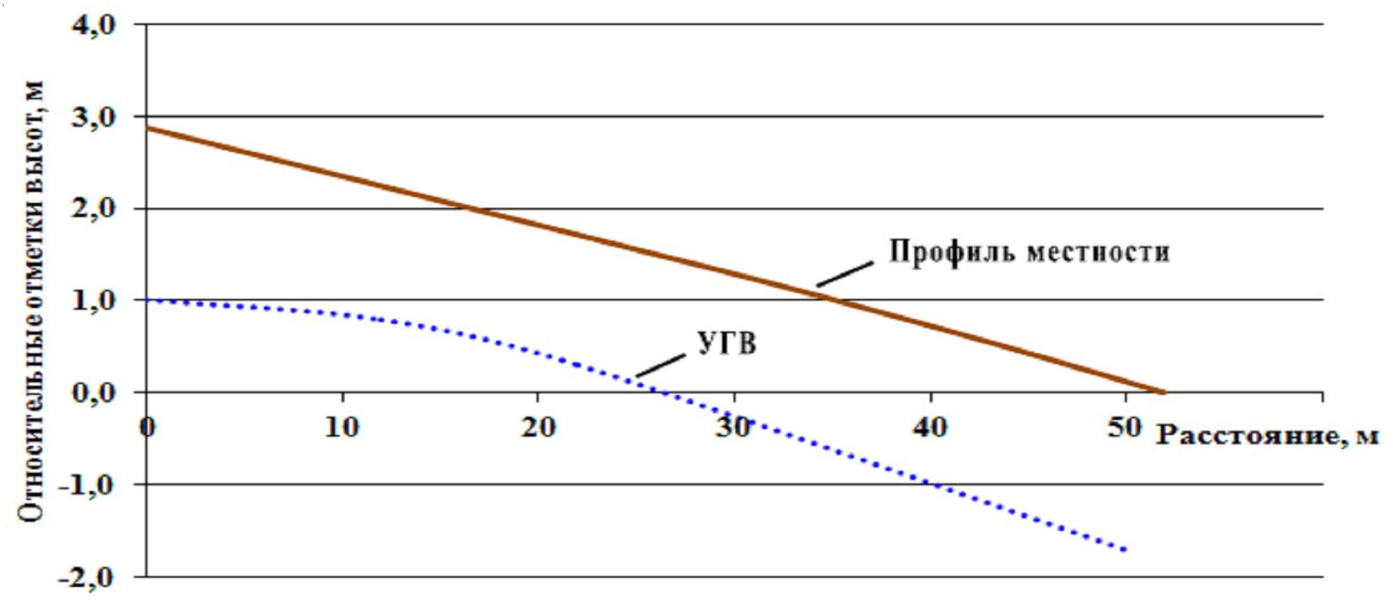

Рис. 4. Профиль УГВ под сосново-березовым насаждением в пос. Латошинка

Таблица 1

Таксационная характеристика сосново-березового насаждения на ключевом участке

\begin{tabular}{|c|c|c|c|c|c|c|}
\hline Порода & $H \mathrm{cp}, \mathrm{м}$ & $D c p$, см & Возраст & Бонитет & Число деревьев на 1 га & Запас, м $^{5} / г \mathrm{a}$ \\
\hline Сосна & $13,9 \pm 3,5$ & $19,5 \pm 8,5$ & 32 & $\mathrm{I}$ & 346 & 77,9 \\
\hline Береза & $19,2 \pm 5,9$ & $21,1 \pm 9,0$ & 32 & I & 159 & 44,5 \\
\hline
\end{tabular}

Таблица 2

Оценка жизнеспособности деревьев на ключевом участке

\begin{tabular}{|l|c|l|c|c|}
\hline \multicolumn{1}{|c|}{$\begin{array}{c}\text { Качественное состояние } \\
\text { деревьев }\end{array}$} & \multicolumn{2}{c|}{$\begin{array}{c}\text { Категория состояния } \\
\text { (жизнеспособности) деревьев }\end{array}$} & \multicolumn{2}{c|}{ Количество деревьев, шт. } \\
\cline { 3 - 5 } Хорошее & 1 & Без признаков ослабления & 185 & 78 \\
\hline \multirow{2}{*}{ Удовлетворительное } & 2 & Ослабленные & 8 & 4 \\
\hline \multirow{3}{*}{ Неудовлетворительное } & 3 & Сильно ослабленные & - & - \\
\cline { 2 - 5 } & 4 & Усыхающие & 3 & 2 \\
\hline & 5 & Сухостой текущего года & - & 6 \\
\cline { 2 - 5 } & 6 & Сухостой прошлых лет & 196 & 90 \\
\hline
\end{tabular}




\section{ЭКОЛОГИЯ И ПРИРОДОПОЛЬЗОВАНИЕ}

сухая осень 2014 г., повлекшие за собой атмосферную и почвенную засуху. Близкое залегание УГВ обеспечивает достаточное питание для деревьев сосны, но в засушливые годы, возможно, может быть недостаточно для березы, в связи с поверхностным расположением ее корневой системы.

В целом жизнеспособность сосново-березовых лесных культур на обследованном участке более чем приемлема для данных лесорастительных условий.

Заключение. Высокий класс бонитета 30 летних сосны и березы, а также высокая сохранность деревьев свидетельствует об оптимальных условиях произрастания лесных культур на севере пригородной зоны Волгограда. Рекомендуется провести вырубку сухостойных и суховершинных деревьев, дополнительных агротехнических уходов за почвой не требуется.

На севере Волгограда при проведении лесокультурных работ в условиях сухого бора (A1) на почвах легкого гранулометрического состава следует рекомендовать кулисный способ смешения сосны с березой для создания высокопродуктивных, устойчивых к неблагоприятным климатическим условиям и обладающих высокими декоративными свойствами защитных лесных насаждений.

\section{ПРИМЕЧАНИЕ}

${ }^{1}$ Работа выполнена по теме Государственного задания ФНЦ агроэкологии РАН (регистрационный номер АААА-А16-116122010038-9).

\section{СПИСОК ЛИТЕРАТУРЫ}

1. Брылев, В. А. Крупнейшие карьеры Волгоградской области и их геоэкологическое состояние / В. А. Брылев, Н. П. Дьяченко, С. И. Пряхин, Н. М. Серегина // Изв. Волгогр. гос. пед. ун-та Сер.: Ест. и физ.-матем. науки. - Волгоград : Перемена, 2007. - № 6. - С. 69-74.

2. Верхунов, П. М. Таксация леса / П. М. Верхунов, В. Л. Черных. - Йошкар-Ола : МарГТУ, 2007. $-395 \mathrm{c}$.

3. Воронков, Н. А. Влагооборот и влагообеспеченность сосновых насаждений / Н. А. Воронков. - М. : Лесная промышленность, 1973. - 184 с.

4. Годунов, Ю. Н. Зеленое кольцо. Опыт создания лесопарковых насаждений и садов вокруг Волгог- рада / Ю. Н. Годунов, А. Г. Грачев, А. Ф. Калашников. Волгоград : Нижне-Волжск. кн. изд-во, 1964. - 102 с.

5. Иозус, А. П. Селекция и гибридизация березы повислой в условиях сухой степи юго-востока европейской территории России / А. П. Иозус, А. А. Завьялов // Международный журнал прикладных и фундаментальных исследований. - 2019. - № 2. - С. 68-72.

6. Манаенков, А. С. Лесомелиорация арен засушливой зоны / А. С. Манаенков. - Волгоград : ВНИАЛМИ, 2014. - 420 c.

7. Манаенков, А. С. Особенности водного режима корнеобитаемого слоя и засухоустойчивость культур сосны / А. С. Манаенков // Лесоведение, 2009. - № 2. - С. 52-61.

8. Мозолевская, Е. Г. Первичные и интегральные показатели состояния насаждений, используемые при мониторинге / Е. Г. Мозолевская // Лесной вестник. -2000 . - № 6. - С. 65-67.

9. Орлов, А. Я. Почвенная экология сосны / А. Я. Орлов, С. П. Кошельков.-М. :Наука, 1971. -323 с.

10. Попов, В. К. Березовые леса центральной лесостепи / В. К. Попов. - Воронеж : Изд-во ВГУ, 2004. $-45 \mathrm{c}$.

11. Попов, В. К. Особенности взаимоотношений сосны и березы в культурах / В. К. Попов // Лесной журнал. - 1980. - С. 9-12.

12. Прозоров, Н. А. Радиальный прирост сосны обыкновенной как один из показателей изменчивости экологических условий ее произрастания на песках степной зоны / Н. А. Прозоров // Лесомелиорация и ландшафт : сб. науч. тр. - Волгоград : ВНИАЛМИ, 1993. - Вып. 1 (105). - С. 145-157.

13. Самусь, Н. А. Инженерная геология Волгоградской агломерации (Практический опыт) / Н. А. Самусь, О. Н. Игнатенко, А. Н. Самусь. М. : Геомаркетинг, 2010. - 304 с.

14. Федорец, Н. Г. Методика исследования почв урбанизированных территорий / Н. Г. Федорец, М. В. Медведева. - Петрозаводск : Карельский научный центр РАН, 2009. - 84 с.

15. Шамирян, К. Г. Сравнительная характеристика сосново-березовых культур с различной схемой смешения / К. Г. Шамирян // Научный журнал Кубанского государственного университета. 2012. - № 81 (07). - Электрон. текстовые дан. - Режим доступа: http://ej.kubagro.ru/2012/07/pdf/02.pdf.

16. Amati, M. From green belts to green infrastructure / M. Amati, L. Taylor // Planning Practice and Research, 2010. - Vol. 25 (2). - P. 143-155.

17. Amati, M. Urban green belts in the twentyfirst century / M. Amaty. - Ashgate, 2008. - 243 p.

18. Chytry, M. Vegetation of the Czech Republic: diversity, ecology, history and dynamics / M. Chetry // Preslia. - 2012. - Vol. 84. - pp. 427-504.

19. Kuehn, M. Greenbelt and Green Heart: separating and integrating landscapes in European city 
regions / M. Kuehn // Landscape and Urban Planning. - 2003. - № 64. - pp. 19-27.

20. Papworth, T. The green noose. Analysis of green belts and proposals for reform / T. Papworth. ASI, 2015. $-64 \mathrm{p}$.

21. Ward Thomson, C. Urban open space in the $21^{\text {st }}$ century / C. Ward Thomson // Landscape and Urban Planning. - 2002. - № 60. - P. 59-72.

22. Zhand, C. Mapping individual tree species in an urban forest using airborne lidar data and hyperspectral imagery / C. Zhand, Q. Fang // Photogrammetric Engineering and Remote Sensin. - 2012. - Vol. 78, №. 10.P. 1079-1087.

\section{REFERENCES}

1. Brylev V.A., Diyachenko N.P., Pryakhin S.I., Seregina N.M. Krupneishie kar'ery Volgogradskoi oblasti i ikh geoekologicheskoe sostoyanie [The largest careers of the Volgograd region and their geoecological state]. Izv. Volgogr. gos. ped. un-ta Ser.: Est. i fiz.-matem. nauki, Volgograd, Peremena, 2007, no. 6, pp. 69-74.

2. Verkhunov P.M., Chernykh V.L. Taksatsiya lesa [Forest taxation]. Iosh-kar-Ola, MarGTU, 2007.395 p.

3. Voronkov N.A. Vlagooborot $i$ vlagoobespechennost sosnovykh nasazh-denii [Moisture and moisture supply of pine plantations]. Moscow, Lesnaya promyshlennost, 1973. 184 p.

4. Godunov Yu.N., Grachev A.G., Kalashnikov A.F. Zelenoe kol'tso. Opyt sozdaniya lesoparkovykh nasazh-denii i sadov vokrug Volgograda [Green belt. The experience of creating forest parks and gardens around Volgograd]. Volgograd, Nizhne-Volzhsk. kn. izd., 1964. 102 p.

5. Iozus A.P., Zaviyalov A.A. Selektsiya i gibridizatsiya berezy povisloi v usloviyakh su-khoi stepi yugo-vostoka evropeiskoi territorii Rossii [Selection and hybridization of wild birch in the conditions of the dry steppe of the south-east of the European territory of Russia]. Mezhdunarodnyi zhurnal prikladnykh $i$ fundamental'nykh issledovanii, 2019, no. 2, pp. 68-72.

6. Manaenkov A.S. Lesomelioratsiya aren zasushlivoi zony [Forest reclamation of dry zone arenas]. Volgograd, VNIALMI, 2014. 420 p.

7. Manaenkov A.S. Osobennosti vodnogo rezhima korneobitaemogo sloya i zasukhoustoichivost' kul'tur sosny [Specific features of the water regime in root-dwelling layer and drought-resistance of pine plantations]. Lesovedenie, 2009, no.2, p. 52-61.

8. Mozolevskaya E.G. Pervichnye i integral'nye pokazateli sostoyaniya nasazhdenii, ispol'zuemye pri monitoring [Primary and integral indicators of the state of stands used in monitoring]. Lesnoi vestnik, 2000, no. 6 , pp. 65-67.
9. Orlov A.Ya., Koshelkov S.P. Pochvennaya ekologiya sosny [Soil ecology of pine]. Moscow, Nauka, 1971. 323 p.

10. Popov V.K. Berezovye lesa tsentral'noi lesostepi [Birch forests of the central forest-steppe]. Voronezh, Izd-vo VGU, 2004. 45 p.

11. Popov, V.K. Osobennosti vzaimootnoshenii sosny i berezy $\mathrm{v}$ kul'turakh [Features of the relationship of pine and birch cultures]. Lesnoi zhurnal, 1980, pp. 9-12.

12. Prozorov N.A. Radialnyi prirost sosny obyknovennoi kak odin iz pokazatelei izmenchivosti ekologicheskikh uslovii ee proizrastaniya na peskakh stepnoi zony [Radial growth of Scots pine as one of the indicators of the variability of the ecological conditions of its growth on the sands of the steppe zone]. Lesomelioratsiya $i$ landshaft : sb. nauch. $t r$. [Forest melioration and landscape: a collection of scientific papers]. Volgograd, VNIALMI, 1993, iss. 1(105), pp. 145-157.

13. Samus N.A., Ignatenko O.N., Samus' A.N. Inzhenernaya geologiya Volgogradskoi aglomeratsii (Prakticheskii opyt) [Engineering geology of the Volgograd agglomeration (Practical experience)]. Moscow, Geomarketing, 2010. 304 p.

14. Fedorets N.G., Medvedeva M.V. Metodika issledovaniya pochv urbanizirovannykh ter-ritorii [Methods of studying the soil in urban areas]. Petrozavodsk, Karelskii nauchnyi tsentr RAN, 2009, 84 p.

15. Shamiryan K.G. Sravnitel'naya kharakteristika sosnovo-berezovykh kultur s razlichnoi skhemoi smesheniya [Comparative characteristics of pine-birch crops with different mixing scheme]. Nauchnyi zhurnal Kubanskogo gosudarstvennogo universiteta, 2012, no. 81 (07). URL: http://ej.kubagro.ru/2012/07/pdf/02.pdf.

16. Amati M., Taylor L. From green belts to green infrastructure. Planning Practice and Research, 2010, vol. 25(2), pp. 143-155.

17. Amati M. Urban green belts in the twentyfirst century. Ashgate, 2008. 243 p.

18. Chytry M. Vegetation of the Czech Republic: diversity, ecology, history and dynamics. Preslia, 2012, vol. 84, pp. 427-504.

19. Kuehn M. Greenbelt and Green Heart: separating and integrating landscapes in European city regions. Landscape and Urban Planning, 2003, no. 64, pp. 19-27.

20. Papworth T. The green noose. Analysis of green belts and proposals for reform, ASI, 2015.64 p.

21. Ward Thomson C. Urban open space in the $21^{\text {st }}$ century. Landscape and Urban Planning, 2002, no. 60 , pp. $59-72$.

22. Zhand C., Fang Q. Mapping individual tree species in an urban forest using airborne lidar data and hyperspectral imagery. Photogrammetric Engineering and Remote Sensing, 2012, vol. 78, no. 10, pp. 1079--1087. 


\section{ЭКОЛОГИЯ И ПРИРОДОПОЛЬЗОВАНИЕ}

\section{Information about the Authors}

Olga Yu. Kosheleva, Candidate of Sciences (Agricultural), Senior Researcher, Federal Scientific Centre of Agroecology, Complex Melioration and Protective Afforestation of the Russian Academy of Sciences, prosp. Universitetskiy, 97, 400062 Volgograd, Russian Federation, olya_ber@mail.ru.

Alexander V. Koshelev, Candidate of Sciences (Agricultural), Leading Researcher, Head of Soil Analysis Laboratory, Federal Scientific Centre of Agroecology, Complex Melioration and Protective Afforestation of the Russian Academy of Sciences, prosp. Universitetskiy, 97, 400062 Volgograd, Russian Federation, alexkosh@mail.ru.

Stanislav S. Shinkarenko, Candidate of Sciences (Agricultural), Senior Researcher, Federal Scientific Centre of Agroecology, Complex Melioration and Protective Afforestation of the Russian Academy of Sciences, prosp. Universitetskiy, 97, 400062 Volgograd, Russian Federation; Associate Professor, Department of Geography and Cartography, Volgograd State University, prosp. Universitetskiy, 100, 400062 Volgograd, Russian Federation, vnialmi@bk.ru.

\section{Информация об авторах}

Ольга Юрьевна Кошелева, кандидат сельскохозяйственных наук, старший научный сотрудник Федерального научного центра агроэкологии, комплексных мелиораций и защитного лесоразведения Российской академии наук, просп. Университетский, 97, 400062 г. Волгоград, Российская Федерация, olya_ber@mail.ru.

Александр Валентинович Кошелев, кандидат сельскохозяйственных наук, заведующий лабораторией анализа почв, ведущий научный сотрудник Федерального научного центра агроэкологии, комплексных мелиораций и защитного лесоразведения Российской академии наук, просп. Университетский, 97, 400062 г. Волгоград, Российская Федерация, alexkosh@mail.ru.

Станислав Сергеевич Шинкаренко, кандидат сельскохозяйственных наук, научный сотрудник Федерального научного центра агроэкологии, комплексных мелиораций и защитного лесоразведения Российской академии наук, просп. Университетский, 97, 400062 г. Волгоград, Российская Федерация; доцент кафедры географии и картографии, Волгоградский государственный университет, просп. Университетский, 100, 400062 г. Волгоград, Российская Федерация, vnialmi@bk.ru. 